\title{
Relationship of Energy and Nutrients Adequacy with Nutritional Status on Young Football Athletes in Central Java
}

\author{
Nur Fauzi ${ }^{1}$, Dewi Pusparini ${ }^{2}$, Supri Hartini ${ }^{3}$, Akhmad Samsu Dukha ${ }^{4}$, Nurul Hidayatun \\ Nasiha $^{5}$, Yanesti Nuravianda Lestari ${ }^{6}$, Mardiana $^{7}$ \\ \{nurfauzi@students.unnes.ac.id ${ }^{1}$, dewipusparini15@gmail.com ${ }^{2}$, suprihartini14@gmail.com ${ }^{3}$ \} \\ Universitas Negeri Semarang, Semarang, Indonesia ${ }^{1,2,3}$
}

\begin{abstract}
This study evaluates the adequacy of energy and nutrient and determines its relationship with young football athletes' nutritional status. This study is an observational analytic study using a cross-sectional design. The subjects are 21 male football athletes of the Central Java Student Sports Education and Training Center and measured their body weight and body height and determined their nutritional status (BMI-for-age and body fat percentage). Dietary pattern as energy and nutrients adequacy was obtained using a semi-quantitative Food Frequency Questionnaire. The results showed that the energy adequacy level was significantly related to BMI-for-age $(\mathrm{p}=0.030)$ but not related to body fat percentage $(\mathrm{p}=0.733)$. The adequacy of nutrients (carbohydrates, fats, proteins) were not related to BMI-for-age $(\mathrm{p}=0.086 ; 0.173 ; 0.322)$ and body fat percentage $(\mathrm{p}=0.289 ; 0.440 ; 0.784)$. It can be concluded that the energy and nutrients adequacy shows a significant relationship with the nutritional status of young football athletes of Central Java's Province.
\end{abstract}

Keywords: nutritional status, body fat percentage, football.

\section{Introduction}

This Athlete's performance can be measured through the individual performance achieved by the athlete. The factors that influence athlete's performance are athlete's training routine, nutritional fulfillment and athlete's physical condition. Nutritional status describes the physical condition that can determine the quality of the athlete while competing and the recovery process.[1]

Football is a team sport that requires a high level of strength and endurance because the game of football lasts quite a long time, namely $2 \times 45$ minutes in normal time. Activities in football can be aerobic and anaerobic activities according to the player's position when competing.[2] Inadequate nutritional intake and low levels of athlete's nutritional status can cause fatigue in the body's recovery process from prolonged fatigue which can reduce performance. The world football federation has stated that the nutritional status of athletes plays a role in the success of the team.[3]

The combination of the right training and adequate nutrition can make the athlete's body morphology better. Athletes with an anthropometric or somatotype structure and body composition that are in accordance with their sport tend to show better sports performance.[4] 
Previous research stated that carbohydrate and protein intake was closely related to the nutritional status of Arjowinangun 1 Pacitan elementary school.[5] However, research on soccer players aged 9-12 years explains that the percentage of carbohydrate and protein adequacy is not related to the nutritional status of footballers.[6]

One of the efforts to develop young football athletes in Indonesia is through the Student Education and Training Center. Education center for student sports training in Semarang, Central Java is a center for developing early age athletes, which focuses on fostering studentage athletes for sports competitions. The athletes are quarantined in order to support the athlete's performance where the training time, physical activity and food consumption patterns of the athletes are well structured.

Adequate nutritional needs can improve the performance of athletes during training or competition by reducing fatigue, risk of disease and injury. Proper nutrition balances the incoming energy intake with the energy expenditure the body needs. This is very important to prevent deficits or excess energy. The risks that occur due to energy deficits are short stature, delayed puberty, menstrual dysfunction, loss of muscle mass and increased susceptibility to fatigue, injury or other diseases. While excess energy can lead to overweight and obesity.[7]

An athlete needs more nutritional intake than people with light physical activity levels. Nutritional needs for athletes are very important to support athlete's performance during training until the recovery process. Adolescence is a period of acceleration and growth that occurs at the age of 10-18 years.[2] Nutrition for adolescent athletes is not only to maintain physical condition and optimize performance during exercise, but is important to meet nutritional needs for growth.[7]

Research from Sacheck and team on nutrition research for adolescent athletes can be known several things that must be considered in determine the right nutrition for young athletes namely: caloric needs, macronutrient, hydration, time and supplements. While there are factors that affect the proper nutrition such as type of exercise, genes, gender, and age.[8]

\section{Methods}

This research is correlational descriptive by using sectional cross design conducted on football athletes in the Center for Student Education and Training Central Java. The subjects in this study were male football athletes with an age range of 15-17 years with total sampling techniques and obtained a total of 21 athletes.[9]

The nutritional status of the study subjects was determined using the BMI/U indicator (Body Mass Index based on Age). BMI is calculated from the weight of the weighing results of the study subjects $(\mathrm{kg})$ and the measurement of height $(\mathrm{m})$ squared. Weight weighing research subjects used digital scales and used microtoises with a measuring capacity of 2 meters and precision of $0.1 \mathrm{~cm}$ to measure height. The BMI measurement results were then associated with the age parameters of the study subjects and assessed based on Z-score (SD). Z-score scores were then categorized into 5 groups, namely very thin $(<-3 \mathrm{SD})$; thin $(>-3 \mathrm{SD}$ to <-2SD); normal (>-2SD to $1 \mathrm{SD}$ ); obese (>1SD to 2SD); and obese (> 2SD).[10]

The body fat percentage of the study subjects was measured using Bioelectrical Impedance Analysis (BIA). The values passed by then categorized into 3 groups namely skinny, good, and acceptable body fat.

The average intake of energy and nutrients was obtained from interviews with research subjects using a semi-FFQ questionnaire (Food Frequency Questionnaire) with a span of 30 
days back. The results of the interview were then converted in the form of units of calories/day for the average energy intake, and grams/day for the average intake of nutrients (carbohydrates, fats and proteins,) which is then compared to Recommended Dietary Allowance (RDA) for adolescents aged 14 - 19 years and multiplied by $100 \%$ using the formula:

$$
\text { Adequacy level of intake }=\frac{\text { Average daily intake (gram/day) }}{\mathrm{RDA}} \times 100 \%
$$

The level of energy adequacy and nutrients is then categorized into 3 groups, namely deficit (<80\% RDA); adequate (80-110\% RDA); and excess (>110\% RDA).[11]

Data on age, weight, height, BMI/U, percent body fat, the average level of energy adequacy and nutrients (carbohydrates, fats, proteins) of the study subjects were analyzed descriptively and presented in table form. The relationship between energy and nutrient adequacy levels with nutritional status and percent of body fat in the study subjects was analyzed using Spearman's Correlation test with a confidence level of $95 \%(\alpha=0.05)$.[12]

\section{Result and Discussion}

The subjects of this study were male football athletes who joined the Center for Student Education and Training and were involved in the collection of research data numbering 21 people with characteristics as presented in table 1 .

Based on table 1 , the average age of football athletes in this study was $16.00 \pm 0.775$ years old with an age range of 15-17 years old and educational background at the upper secondary level. The data showed that all subjects in this study were still classified as adolescent age groups. The average weight and height of athlete $62.48 \pm 7.68 \mathrm{~kg}$ and $168.91 \pm 4.27 \mathrm{~cm}$. The average athlete's Z-Score is $0.34 \pm 0.71$ which means the athlete has a normal body mass index. It can also be seen in table 1 that the average energy intake of athletes is $2027.12 \pm$ 597.00 and for the average intake of athletes macronutrients (carbohydrates, proteins, and fats) is $318.31 \pm 96.55 ; 83.03 \pm 36.19$; and $55.68 \pm 25.27$. Meanwhile, the average energy requirements of athletes are $4138.33 \pm 553.77$ with the average macronutrient requirements (carbohydrates, proteins, and fats) is $569.02 \pm 76.14 ; 206.92 \pm 27.69$ and $114.95 \pm 15.38$. Thus, the average energy adequacy level of athletes is $57.85 \pm 15.91$ and the level of adequacy of macronutrients (carbohydrates, proteins, and fats) is $65.49 \pm 17.28 ; 47.65 \pm 20.15$; and $57.17 \pm 25.46$

Table 1. Characteristics of Research Subjects.

\begin{tabular}{lccc}
\hline Characteristics of Subject $(\mathbf{N}=\mathbf{2 1})$ & Mean \pm SD & Minimum & Maximum \\
\hline Age (years) & $16,00 \pm 0,775$ & 15,00 & 17,00 \\
\hline Body Weight $(\mathrm{kg})$ & $62,48 \pm 7,68$ & 49,05 & 76,50 \\
\hline Height $(\mathrm{cm})$ & $168,91 \pm 4,27$ & 161,00 & 175,60 \\
\hline Z-score (IMT/U) & $0,34 \pm 0,71$ & $-1,40$ & 1,69 \\
\hline Body Fat Percentages & $15,59 \pm 2,34$ & 9,40 & 19,70 \\
\hline Daily intake of Energy and Nutrients & & & \\
$\quad$ Energy (kkal) & $2027,12 \pm 597,00$ & 1228,50 & 3848,00 \\
$\quad$ Carbohydrate (g) & $318,31 \pm 96,55$ & 174,80 & 531,20
\end{tabular}




\begin{tabular}{lccc}
\hline Characteristics of Subject $(\mathbf{N}=\mathbf{2 1})$ & Mean $\mathbf{\text { SD }}$ & Minimum & Maximum \\
\hline Protein $(\mathrm{g})$ & $83,03 \pm 36,19$ & 52,50 & 214,80 \\
Fat $(\mathrm{g})$ & $55,68 \pm 25,27$ & 28,50 & 107,50 \\
\hline Energy and Nutrients Requirements & & & \\
Energy (kkal) & $4138,33 \pm 553,77$ & 2765,04 & 5023,35 \\
Carbohydrate (g) & $569,02 \pm 76,14$ & 380,19 & 690,71 \\
Protein (g) & $206,92 \pm 27,69$ & 138,25 & 251,17 \\
Fat (g) & $114,95 \pm 15,38$ & 76,81 & 139,54 \\
\hline Sufficient Level of Energy and Nutrients & & & \\
Energy (kkal) & $57,85 \pm 15,91$ & 35 & 102 \\
Carbohydrate (g) & $65,49 \pm 17,28$ & 36 & 102 \\
Protein (g) & $47,65 \pm 20,15$ & 26 & 114 \\
Fat (g) & $57,17 \pm 25,46$ & 26 & 117 \\
\hline
\end{tabular}

Table 2. Distribution of Nutrition Intake Category, Nutritional Status, and Percent of Athletes Body Fat.

\begin{tabular}{lcc}
\hline \multicolumn{1}{c}{ Variable } & n & \% \\
\hline Adequacy Level of Energy & 20 & $95,24 \%$ \\
Deficit & 1 & $4,76 \%$ \\
Adequate & 17 & $81,95 \%$ \\
\hline Adequacy Level of Carbohydrates & 4 & $19,05 \%$ \\
Deficit & & \\
Adequate & 20 & $95,24 \%$ \\
\hline Adequacy Level of Protein & 0 & \\
Deficit & 1 & $4,76 \%$ \\
Adequate & & \\
Excessive & 18 & $85,71 \%$ \\
\hline Adequacy Level of Fat & 2 & $9,5 \%$ \\
Deficit & 1 & $4,76 \%$ \\
Adequate & & \\
Excessive & 17 & $80,95 \%$ \\
\hline BMI for Age & 4 & $19,05 \%$ \\
Normal & & \\
Overweight & 5 & $23,81 \%$ \\
\hline Body Fat Percentage & 12 & $57,14 \%$ \\
Skinny & 4 & $19,05 \%$ \\
Good & & \\
Acceptable & & \\
\hline & &
\end{tabular}

Based on table 2, most athletes $(89.54 \%)$ deficit in energy and nutrient adequacy (carbohydrates, proteins, and fats). There are $4.76 \%$ of athletes who have an adequate intake of energy, and $19.05 \%$ of athletes who have adequate intake of carbohydrate, while in fat adequacy there are only $9.5 \%$ of athletes whose fat intake is adequate and $4.76 \%$ of athletes who experience excessive protein and fat intake. 
Tabel 3. Distribution of Relationship between Energy Adequacy Level and Nutritional Intake with Nutritional Status of Athletes.

\begin{tabular}{|c|c|c|c|c|c|c|c|}
\hline \multirow{3}{*}{ Adequacy Level } & \multicolumn{4}{|c|}{ Nutritional status } & \multirow{2}{*}{\multicolumn{2}{|c|}{ Total }} & \multirow{3}{*}{$P$ Value } \\
\hline & \multicolumn{2}{|c|}{ Normal } & \multicolumn{2}{|c|}{ Overweight } & & & \\
\hline & $\mathbf{n}$ & $\%$ & $\mathbf{n}$ & $\%$ & $\mathbf{N}$ & $\%$ & \\
\hline \multicolumn{8}{|l|}{ Energy } \\
\hline Defisit & 16 & $80 \%$ & 4 & $20 \%$ & 20 & $100 \%$ & \multirow{3}{*}{$0,030^{*}$} \\
\hline Adequate & 1 & $100 \%$ & 0 & $0 \%$ & 1 & $100 \%$ & \\
\hline Excessive & - & - & - & - & - & - & \\
\hline \multicolumn{8}{|l|}{ Carbohydrates } \\
\hline Defisit & 14 & $82,4 \%$ & 3 & $17,6 \%$ & 17 & $100 \%$ & \multirow{3}{*}{0,086} \\
\hline Adequate & 3 & $75 \%$ & 1 & $25 \%$ & 4 & $100 \%$ & \\
\hline Excessive & - & - & - & - & - & - & \\
\hline \multicolumn{8}{|l|}{ Protein } \\
\hline Defisit & 16 & $80 \%$ & 4 & $20 \%$ & 20 & $100 \%$ & \multirow{3}{*}{0,322} \\
\hline Adequate & - & - & - & - & - & - & \\
\hline Excessive & 1 & $100 \%$ & 0 & $0 \%$ & 1 & $100 \%$ & \\
\hline \multicolumn{8}{|l|}{ Fat } \\
\hline Defisit & 15 & $83,3 \%$ & 3 & $16,7 \%$ & 18 & $100 \%$ & \multirow{3}{*}{0,173} \\
\hline Adequate & 2 & $100 \%$ & 0 & $0 \%$ & 2 & $100 \%$ & \\
\hline Excessive & 0 & $0 \%$ & 1 & $100 \%$ & 1 & $100 \%$ & \\
\hline
\end{tabular}

Based on the data, it can be known that the level of adequacy/fulfillment of energy and nutrition of youth football athletes in Central Java in 2019 has not been sufficient due to the lack of portion of food consumed and the high activity carried out daily by athletes. This can be seen from the average level of energy adequacy and nutrients (carbohydrates, proteins, fats) athletes only amounted to $57.85 \pm 15.91 \%$ and $65.49 \pm 17.28 \%$; $47.65 \pm 20.15 \%$; and $57.17 \pm$ $25.46 \%$. Therefore, it is necessary to reconsider the athlete's diet intake and adequate energy intake for athletes must be in line with the athlete's activity because optimal physical condition during the competition will not be achieved if it is not supported by adequate energy and nutrient intake. A balanced intake of nutrients can affect an athlete's performance during a match. [13]

The results of this research correlation test analysis show that there is a significant relationship in the positive direction between energy adequacy level and nutritional status /BMI-for-Age $(\mathrm{p}=0.030)$ This is in line with previous research which states that there is a relationship between energy adequacy and nutritional status.[14] The results obtained from this study from the level of energy adequacy are mostly heavy deficits, but BMI results are mostly normal, this is likely influenced by indicators of nutritional adequacy obtained from dietary recall in this study, namely FFQ that reflects nutritional adequacy that focuses on the balance of nutrient composition, so that because most of the nutrients consumed are not adequate, the analysis of FFQ is a deficit.[15]

There is a significant relationship between the level of energy adequacy and nutritional status in this study, namely the average intake of subjects is in the category of less than $2027.12 \mathrm{kcal} / \mathrm{day}$. Energy adequacy is a direct factor that can affect nutritional status. For 
subjects that have a good level of energy adequacy then the nutritional status will also be good. It is known that the RDA for energy in adults aged 16-18 years is $2650 \mathrm{kcal}$ for males.

Energy is the result of the metabolism of proteins, fats, and carbohydrates. Energy is required of the body for growth, metabolism, utilization of foodstuffs, and activity. The energy that comes through food must be balanced with the needs. The imbalance of energy input with long-term needs can cause nutritional problems. Therefore, it is necessary to reconsider the consumption pattern, and also excessive physical activity should be followed by a good energy intake as well. Dishes and foods when consumed in the right amount and way will produce a healthy nutritional state, a healthy state of daily nutrition will increase intellectual development the productivity of a person and achieve optimal achievements.[14]

The results showed no correlation between energy adequacy levels and athletes' body fat percentage and based on the results of the correlation test the relationship direction in this study was positive with weak correlation strength $(\mathrm{r}=0.079, \mathrm{p}=0.733)$. This shows that if the lower the level of energy consumption, the smaller the percentage of body fat, this is evidenced by as many as 20 respondents $(95.24 \%)$ football athletes with a adequacy level of energy deficit and one responden $(4,76 \%)$ with a adequacy level of energy adequate have a diverse percentage of body fat, namely 5 respondents $(23.81 \%)$ in the skinny category, 12 respondents $(57.14 \%)$ in the good category and 4 respondents $(19.05 \%)$ in the acceptable category. The results of this study are in line with previous research in Semarang which stated that there is no relationship of energy consumption level with body fat percentage with $\mathrm{p}=$ $0.528(\mathrm{p}>0.05) \cdot[16]$

The main components of success in exercise can be influenced by adequate energy intake to support calorie expenditure and increase strength, endurance, muscle mass, and physical health. If the athlete's intake is inadequate, it will affect the performance of the athlete. The efficiency of body movement, intensity, and length of exercise also affect the amount of energy an athlete needs during exercise. Each sport has different nutritional needs, but in general, energy is a priority nutrient.[17]

Body Mass Index is not a benchmark of an athlete's nutritional status, so it does not describe body composition and does not represent a percent of body fat, and is inaccurate for predicting excess fat mass and muscle mass.[18] Body composition and weight contribute to exercise performance. Weight loss can affect an athlete's speed, endurance, and power, while body composition (fat mass and fat-free body mass) can produce strength, agility, and athlete appearance. [19]

Spearman's correlation test results showed no significant association between carbohydrate adequacy levels, fat adequacy levels, and protein adequacy levels with nutritional status $(\mathrm{p}=0.086 ; 0.173 ; 0.322)$ and percent body fat $(\mathrm{p}=0.289 ; 0.440 ; 0.784)$. The positive correlation between carbohydrate adequacy level, protein adequacy level, and fat adequacy level with nutritional status in this study showed that although there is no relationship but has a tendency to have a comparable relationship for subjects who have a higher nutritional status tend to have a high level of protein, fat, and carbohydrates adequacy as well. However, there is a negative correlation between carbohydrate adequacy and percent body fat $(r=-0.243)$ this indicates that if the lower the level of carbohydrate adequacy, the greater the percentage of body fat, These results are also comparable with previous studies that there is no significant relationship between the level of energy adequacy, protein adequacy level, fat adequacy level, and carbohydrate adequacy level with nutritional status. [20]

There is no significant relationship, possibly due to too few subjects and the level of adequacy of subjects tends to be homogeneous (most subjects have deficit levels of energy, protein, fat, and carbohydrate adequacy). 


\section{Conclusion}

It can be concluded that the level of energy adequacy has a significant relationship with BMI for age, but not with the percentage of body fat. Likewise, the level of nutrient adequacy (carbohydrates, fat, protein) did not have a significant relationship with BMI for age and body fat percentage. The recommendation for further research is that more in-depth research can be carried out by adding several other variables such as monitoring physical activity, and other indicators such as waist circumference to determine the relationship with the level of energy adequacy and nutrition of athletes.

\section{References}

[1] Mardiana M, Budiono I, Lestari YN, Prameswari GN. Relationship of Energy and Nutrient Intakes on Nutritional status of Young Athletes in Semarang, 362(Acpes). 2019; 305-309.

[2] Dieny FF, Putriana D. Hydration Status Before and After Youth Football Athlete Training. Indonesian Nutrition Journal (The Indonesian Journal of Nutrition). 2016; 3(2): 86-93.

[3] Muthmainnah I, Prabowo S. The Correlation of Energy Intake and Macronutrients (Protein, Carbohydrate, Fat) with Fitness $\left(\mathrm{VO}_{2} \max \right)$ in Teen Athletes at Harbi Soccer School, Jurnal Kesehatan Masyarakat Mulawarman (JKMM), 1(1), p. 24. 2019.

[4] Penggalih MT, Pratiwi D, Fitria F, Sari MP, Narruti NH, Winata IN, Fatimah F, Kusumawati MD. Somatotype Identification, Nutritional Status and Dietary of Teenage Athletes Stop and Go Sports. Jurnal Kesehatan Masyarakat. 2016; 11(2):222.

[5] Amin N, Lestari Y. Relationship of Energy and Nutrients Adequacy on Nutritional Status of Football Players Aged 9-12 Years. Proceeding of Surabaya International Health Conference. 2017; 527-533.

[6] Isdaryanti C. Protein Energy Intake, Nutritional Status, and Learning Achievement of Arjowinangun 1 Elementary School Children in Pacitan. Universitas Gajah Mada. 2017.

[7] Wright CM, Duquesnay PJ, Anzman-Frasca S, Chomitz VR, Chui K, Economos CD, ... Sacheck JM. Study protocol: The Fueling Learning through Exercise (FLEX) study - A randomized controlled trial of the impact of school-based physical activity programs on children's physical activity, cognitive function, and academic achievement. BMC Public Health. 2016; 16(1):1-12.

[8] Sacheck J, Schultz N. Optimal Nutrition for Youth Athletes: Food Souerces and Fuel Timing. National Youth Sports Health \& Safety Institute. 2016.

[9] Sugiyono. Quantitative Research Methods. Bandung: Alfabeta, cv. 2019. 140.

[10] Peraturan Menteri Kesehatan Republik Indonesia Nomor 2 Tahun 2020. Anthropometric Standards for Assessment of Children's Nutritional Status. Kemenkes RI. 2020.

[11] Widyakarya Nasional Pangan dan Gizi. Strengthening Food Security and Improving Nutrition Based on Independence and Local Wisdom. Jakarta: Lembaga Ilmu Pengetahuan Indonesia. 2012.

[12] Dahlan MS. Statistics for Descriptive, Bivariate and Multivariate Medicine and Health. Dilengkapi Aplikasi Menggunakan SPSS. 6th edition. Jakarta: Epidemiologi Inonesia; 2014.

[13] Fink HH, Mikesky AE. Practical Application in Sports Nutrition. 4th edition. Massachusetts, USA: Jones and Bartlett Learning. 2015. 24-50

[14] Siregar NS. Lasar Dani DP. Relationship between Energy Adequacy Level and Nutritional Status of North Sumatra Wrestling Athletes on Education center for student sports training. Sains Olahraga : Jurnal Ilmiah Ilmu Keolahragaan. 2019; 2(1): p. 10.

[15] Gurnida DA, Nur'aeny N, Hakim DL, Susilaningsih FS, Herawati MD, Rosita I. Correlation between nutritional adequacy levels with body mass index of elementary school students grades 4 , 5, and 6. Padjadjaran Journal of Dental Researchers and Students. 2020; 4(1):43.

[16] Salamah R. Relationship between Nutritional Intake, Physical Activity, and Body Fat Percentage with Physical Fitness. Media Kesehatan Masyarakat Indonesia. 2019; 18(2):14-18.

[17] Rahmawati M. The Right Menu for Athletes Food, the Most Popular 11 Sports. Yogyakarta: 
Pustaka Baru Press. 2015.

[18] Ode JJ, Pivarnik JM, Reeves MJ, Knous JL. Body mass index as a predictor of percent fat in college athletes and nonathletes. Medicine and Science in Sports and Exercise. 2007; 39(3), pp. 403-409.

[19] Weatherwax D. Body Composition and Its Effect on the Sports Performance Spectrum. NSCA Sport Nutrition. 2008; 7(5):6-7.

[20] Soraya D, Sukandar D, Sinaga T. The relationship between nutritional knowledge, nutritional adequacy level, and physical activity with nutritional status of junior high school teachers. Jurnal Gizi Indonesia (The Indonesian Journal of Nutrition), (2017); 6(1):29-36. 